\begin{tabular}{|c|c|c|}
\hline INESEG & $\begin{array}{l}\text { INTERNATIONAL } \\
\text { ENGINEERING, } \\
\text { SCIENCE AND } \\
\text { EDUCATION } \\
\text { GROUP } \\
\text { (PUBLISHER) }\end{array}$ & 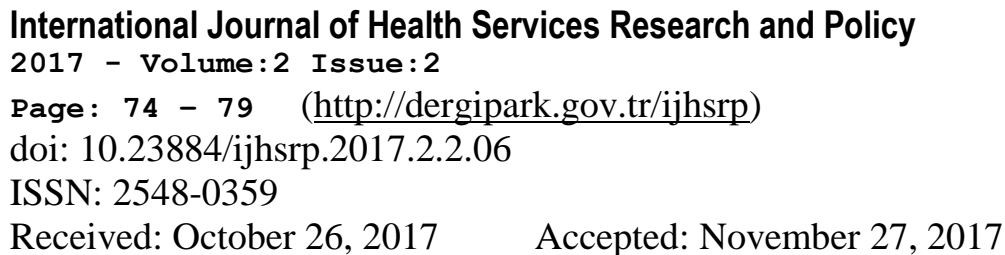 \\
\hline
\end{tabular}

\title{
NICOTINE DEPENDENCE LEVEL OF UNIVERSITY STUDENTS RELATING TO TYPE OF EDUCATION AND GENDER
}

\author{
Songül DOĞANAY $Y^{1}$ Ayla Eren ÖZDEMIR ${ }^{2}$, Şeyma TRABZON ${ }^{2}$ \\ ${ }^{1}$ Sakarya University, Faculty of Medicine Department of Physiology \\ ${ }^{2}$ Sakarya University, Health Services Vocational School \\ Corresponding author; E-mail: aylae@ sakarya.edu.tr
}

\begin{abstract}
Smoking is an increasingly important public health problem because of the health problems it causes. We aimed to investigate whether there is a relationship between nicotine addiction level, education type and gender in vocational school of health services students who smoke in the study.

This descriptive study was conducted with first and second year university students studying in various associate degree programs in health field. In the study, questionnaire forms were used to determine sociodemographic conditions prepared with scientific support as data collection tool. Nicotine dependence was determined by the Fagerström nicotine dependence test (FNBT). A total of 72 students attending 34 daytime education and 38 nighttime education courses participated in the research. 47 of the participants were female(\% 65.3) and $25(\% 34.7)$ male. In our study, 57 of the students are between the ages of 17-20 and the remaining 15 are over 21 years old. 29 of the participants in the study were low-level addicts, 34 were moderately addicts, and 9 were high-level nicotine addicts. When the intergender dependency levels are examined, 58.8\% of the female students and $41.2 \%$ of the male students are moderately addicted. $52.6 \%$ of evening education students are moderately dependent, $41.2 \%$ of daytime education students are moderately and lowly dependent. There was no statistically significant difference between gender, type of education and nicotine addiction. There was no significant difference between the level of dependence, education type and gender in nicotine dependence level study using FNBT. The addiction rate was also higher for women. Most of the students who had nighttime learning were mostly moderate nicotine addicts.
\end{abstract}

Key Words: Nicotine dependence, gender, type of education, students.

\section{INTRODUCTION}

Smoking is an important public health problem due to health problems. Cigarette addiction is a complicated process in which environmental and genetic influences play a role together. Psychological 
factors and habits are like being the main factor in nicotine addiction. Nicotine is an addictive substance derived from the leaves of a tobacco plant [1].

Nicotine acts through specific nicotinic acetylcholine receptors and stimulates dopamine release thought to be responsible for the acute rewarding effect of nicotine. It increases the "reward cycle" effect of dopaminergic neurons in the anterior nicotine and increases the release of neurotransmitters such as acetylcholine, norepinephrine, dopamine and serotonin in the presynaptic region[2]. It is known that while acetylcholine causes an increase in performance and memory capacity, the release of dopamine and norepinephrine decreases pleasure and appetite[1]. Smoking cigarettes have been shown to improve performance in nicotine-free jobs[3].

Nicotine dependence has a similar effect on heroin and cocaine dependence. Nicotine dependence is a major cause of continued cessation behavior and failure of treatment interventions [4]. The Fagerstrom Nicotine Dependence Test (FNBT) is often used in studies that measure the prevalence of nicotine dependence. Studies have shown that FNBT is correlated with biochemical measurements and that scales of scale are effective in assessing cigarette smoking and treatment outcome [5].

The purpose of this study is to examine whether there is a relationship between the level of nicotine addiction and the type of education (day and night) and gender in students studying in associate degree programs.

\section{MATERIAL AND METHOD}

\subsection{Participants}

This descriptive study was conducted among first- and second-year students studying at the Health Services Vocational School in 2017. A total of 72 smokers participated in the study. During the data collection phase, students were accepted orally and the questionnaires were only applied to students who agreed to participate. The study started with the approval of the Ethics Committee of Sakarya University Medical Faculty.

\subsection{Questionnaire Forms}

A questionnaire prepared with scientific resources was used as data collection tool. Attendance, gender, age, education class, type of education, social security, parental status, parental education status, number of siblings, etc. Questions about identifying sociodemographic conditions of participants about the descriptive characteristics were directed. After receiving information about the questionnaire and the FNBT questionnaire, they were asked to fill in by the students who agreed to participate.

\subsection{Fagerstrom Nicotine Addiction Test}

FBNT was developed by Karl O. Fagerstrom to assess the level of physical dependence on cigarettes [5]. The exam consists of 6 questions. The questions were closed. Addiction increases score scale when smoking increases. Those who score 0-2 on the scale are mild, and 
those who score 8-10 on a scale of 3-7 are considered heavy nicotine addicts. FBNT is also used in smoking cessation clinics.

\subsection{Statistical Analysis}

Completed questionnaires were evaluated with SPSS 22 statistical program and analyzed statistically. The data show the arithmetic mean \pm standard deviation and the number and percentage values.

\section{RESULTS}

When the distribution of the students according to sociodemographic characteristics is examined; Thirty-seven $(65.3 \%)$ of the participants were female and 25 were male $(34.7 \%)$. In our study, $79.2 \%$ of the students were between the ages of 17-20 and the remaining $20.8 \%$ were over 21 years old. $49(68.1 \%)$ of the students were in the first class, $23(31.9 \%)$ in the second class, $47.2 \%$ in the first class and 52.8 in the second class. $59.7 \%$ of the students are primary school graduates and 48.6 $\%$ are high school graduates. $34.7 \%$ had an authoritarian family. Moreover, $48.6 \%$ of the total family income is between 3000-5000 TL (Table 1).

Table 1. Distribution of Students by Socio-Demographic Characteristics

\begin{tabular}{|c|c|c|}
\hline Participants Characteristics & $n=637$ & $\%$ \\
\hline \multicolumn{3}{|l|}{ Gender } \\
\hline Woman & 47 & 65.3 \\
\hline Men & 25 & 34.7 \\
\hline \multicolumn{3}{|l|}{ Class } \\
\hline 1st Class & 49 & 68.1 \\
\hline 2 st Class & 23 & 31.9 \\
\hline \multicolumn{3}{|l|}{ Type of Study } \\
\hline Daytime education & 38 & 47.2 \\
\hline Nighttime education & 34 & 52.8 \\
\hline \multicolumn{3}{|l|}{ Educational status of mother } \\
\hline Illiterate & 5 & 6.9 \\
\hline Literate & 8 & 11.1 \\
\hline Primary school graduate & 43 & 59.7 \\
\hline High school graduate & 14 & 19.4 \\
\hline Graduated from a Universty & 2 & 2.8 \\
\hline \multicolumn{3}{|l|}{ Educational status of father } \\
\hline Illiterate & 1 & 1.4 \\
\hline Literate & 2 & 2.8 \\
\hline Primary school graduate & 26 & 36.1 \\
\hline High school graduate & 35 & 48.6 \\
\hline Graduated from a Universty & 8 & 11.1 \\
\hline Family Attitude & & \\
\hline
\end{tabular}




\begin{tabular}{|l|cc|} 
Authoritarian & 25 & 34.7 \\
Democratic & 22 & 30.6 \\
Irrelevant & 2 & 2.8 \\
Protector & 23 & 31.9 \\
Friend relationships & & \\
Positive & 54 & 75.0 \\
Verbal controversial & 14 & 19.4 \\
Physical conflict & 4 & 5.6 \\
Living place & & \\
Provincial center & 41 & 23.3 \\
District & 20 & 11.4 \\
Village & 11 & 6.3 \\
Income rate & & \\
1000TL & 4 & 5.6 \\
1000-3000TL & 35 & 48.6 \\
3000-5000TL & 27 & 37.5 \\
5000-10000TL & 6 & 8.3 \\
\hline
\end{tabular}

In our study of all participants smoking, 29 of the students were low-level dependent, 34 were moderately addicted, and 9 were high-level nicotine addicts. $58.8 \%$ of female students and $41.2 \%$ of male students were moderately addicted; $52.6 \%$ of them were dependent on the moderate level and 41.2 $\%$ of the primary education students were moderately and lowly dependent on the type of learning and nicotine dependence (Table 2).

Table 2. Nicotine Dependence Levels of Gender and Learning Attendance by Participants

\begin{tabular}{|l|c|c|c|c|c|}
\hline \multirow{2}{*}{$\begin{array}{c}\text { Nicotine Dependency } \\
\text { Level }\end{array}$} & \multicolumn{2}{|c|}{ Type of Study } & \multicolumn{2}{c|}{ Gender } & \multirow{2}{*}{ Total (\%) } \\
\cline { 2 - 6 } & $\begin{array}{c}\text { Daytime } \\
\text { education }\end{array}$ & $\begin{array}{c}\text { Nighttime } \\
\text { education }\end{array}$ & Woman & Man & \\
\hline Low & $14(41.2 \%)$ & $15(39.5 \%)$ & $20(69 \%)$ & $9(31 \%)$ & $29(100 \%)$ \\
\hline Medium & $14(41.2 \%)$ & $20(52.6 \%)$ & $20(\% 58,8)$ & $14(41.2 \%)$ & $34(100 \%)$ \\
\hline High & $6(7.9 \%)$ & $3(7.9 \%)$ & $7(77.8 \%)$ & $2(22.1 \%)$ & $9(100 \%)$ \\
\hline Total & $34(100 \%)$ & $38(100 \%)$ & $47(65.3 \%)$ & $25(34.7 \%)$ & $72(100 \%)$ \\
\hline
\end{tabular}

\section{DISCUSSION}

In recent years, smoking cessation campaigns and published legislation, particularly in developed countries, have shown that smoking rates are significantly reduced. There has been an increase in the number of cessation-quitting treatments in our country, especially after leaving cessation in closed areas [6]. 
Health professionals should be sampled by the community and they should not smoke because they are health educators at the same time. Health workers' cigarettes receive messages about the health effects of smoking [7]. For this reason, it is important to know the smoking status of this group, the levels of nicotine dependence and the factors affecting it.

Health workers need to be taken as an example by the society and at the same time they should be non-smokers because they are health educators. Health workers' smoking, hurts messages about the health effects of cigarettes[7]. For this reason, it is important to know the smoking status of this group and the levels of nicotine addiction and the factors that affect it.

Nicotine dependence is the most common and most important type of substance abuse because smoking is easy and inexpensive and its use is legal. Studies have defined the 15-24 age group as a risky group in terms of the development of substance dependence [8]. In our study, $79.2 \%$ of the students were between the ages of 17-20. Studies conducted for various university students have found smoking rates between $25 \%$ and $63.2 \%$ [9, 10]. Given this high rate, there must be a social awakening in the fight against smoking and special quarantine campaigns should be prepared especially for young people, certain age groups and occupations.

All of our participants are smoking. When the dependency levels of the participants are examined, $34 \%$ are moderate $29 \%$ are low level nicotine addicts.

It is inevitable that if the younger generation of twenty-year-olds continue to smoke, they will have to be highly dependent on their progressive ages. When the distribution of nicotine dependence level of participants and gender were evaluated, it was seen that women were more dependent on the subject. In our study, $58.8 \%$ of the females and $41.2 \%$ of the males were moderate nicotine addicts, but our results were statistically significant. In some studies it has been reported that there may be an increase in cigarette use with an increase in the level of education in women. A study conducted by university students found that $41.3 \%$ of female students and $16.9 \%$ of male students started cigarette smoking at first and second year of university [11]. In a study of 41.5 of the overall average age at which smoking levels were assessed in women and men, $38.2 \%$ of the women were found to be nicotine addicted at high rates [12]. This result supports our hypothesis for the future.

Due to the current conditions, it is becoming increasingly common for a majority of people to work day and study night. Under this preference, universities open night programs of many undergraduate and associate degree programs. When we compared the type of learning with nicotine addiction in our study, $52.6 \%$ of the students in the nighttime and $41.2 \%$ of the daytime students were moderately addicted. Studies on smoking habit and nicotine addiction were generally compared with the sociodemographic characteristics of the students and the relation between the type of education and dependency ratio was not questioned. This result in our study may explain that students smoke more to keep their mental activities active until late at night. This may be related to the fact that nicotine has a stimulating effect at low doses, while at higher doses it may initially correlate with sedative effects after stimulants [13]. Smoking cigarettes have been shown to improve performance in nicotine-free jobs. In a study conducted, it was reported that nicotine patches were adhered to non-smokers to develop attention and alertness [14]. 
As a result; In our study of nicotine addiction level using FNBT, there was no significant difference in nicotine addiction level, age, gender and education type. Nicotine addiction rates were higher in females. We think that factors affecting nicotine dependence can be elucidated by questioning parameters such as age and gender as well as the presence of an additional illness (especially depression, anxiety), age of smoking initiation, social status, smoking history in family and close friends.

\section{REFERENCES}

[1] Demir, T., Sigara Bağımlılı̆̆ı. İstanbul Üniversitesi Cerrahpaşa Tıp Fakültesi Sürekli Tıp Eğitimi Etkinlikleri, 2008. 62: p. 231-238.

[2] Sofouglu, M., et al., Cognitive Effects of Nicotine. 2014.

[3] Duygu Kumbul Doğuç, et al., Effects of Nicotine on Lipid Peroxidation and Nitric Oxide Levels at Rat's Hippocampus. Turkish Journal of Clinical Biochemistry 2008. 6(3): p. 81-86.

[4] Örsel, O., et al., Sigara bırakmada nikotin bağımlılık düzeylerinin tedavi sonuçlarına etkisi. Solunum Hastalıkları, 2005. 16(3): p. 112-18.

[5] TODD F. HEATHERTON, et al., The Fagerström Test for Nicotine Dependence: a revision of the Fagerstrom Tolerance Questionnaire. Addiction, 199186 (9): p. 1119-1127.

[6] INCE, M. and M.C. KOÇAK, Kamu Kurumlarında Çalışan Personelin Sigara Kullanma Alışkanlıkları. Electronic Turkish Studies, 2017. 12(13).

[7] Okutan, O., et al., Sigara içen sağlık personelinde nikotin bağımlılık düzeyini etkileyen faktörler. Tüberküloz ve Toraks Dergisi, 2007. 55(4): p. 356-363.

[8] Kutlu, R., K. Marakoğlu, and S. Çivi, Selçuk Üniversitesi Tıp Fakültesi hemşirelerinde sigara içme durumu ve etkileyen faktörler. Cumhuriyet Üniversitesi Tıp Fakültesi Dergisi, 2005. 27(1): p. 29-34.

[9] Çapık, C. and Ş. Özbıçakcı, Hemşirelik yüksekokulu öğrencilerinin sigara bağımlılık düzeyleri. Uluslararası İnsan Bilimleri Dergisi 2007. 4(2): p. 1.

[10] Akfert, S.K., E. Çakıcı, and M. Çakıcı, Üniversite öğrencilerinde sigara-alkol kullanımı ve aile sorunları ile ilişkisi. Anadolu Psikiyatri Dergisi, 2009. 10(40): p. 40-47.

[11] Demirel, Y. and R. Sezer, Sivas bölgesi üniversite öğrencilerinde sigara kullanma sıklı̆̆ı. Erciyes Tup Dergisi, 2005. 27(1): p. 1-6.

[12] Çelepkolu, T., et al., Sigara kullanıcılarda nikotin bağımlılık düzeyinin yaş ve cinsiyetle ilişkisi: Diyarbakır örneklemi. Dicle Tip Dergisi, 2014. 41(4).

[13] GÜZEL, A., Tütün Bitkisi ve Farmakolojik Özellikleri; Gerçekten Şeytan Otu Mu? Güncel Göğüs Hastallklarl Serisi 2016. 4 (1): p. 22-26.

[14] Rezvani AH, L.E., Cognitive Effects of Nicotine. Biological Psychiatry 2001. 49: p. 258-267. 